\title{
COVID-19. Considerations about the overwhelming and indiscriminate scientific information and its dissemination
}

During this time, and for a few months now, with the world going through a pandemic caused by a new virus, our days have been flooded by a deluge of information.

Since the first report on a small group of patients in China who suffered pneumonia due to a new coronavirus in December 2019, until now, thousands of research articles, expert opinions (from specialists in infectious diseases, public health medical officers, epidemiologists, pharmacologists, biologists, among many others), institutional and university publications, recommendations and guidelines issued by agencies and international, regional and national ministries of health, scientific societies, etc. from all over the world, among other data, may be accessed almost immediately as the pandemic unfolds.

Medical and non-medical care providers working directly or indirectly with patients and the public in general want information about this new disease and how to prevent and manage it.

Therefore, several questions arise in view of the need to know about how the pandemic progresses.

How should scientific information published about COVID-19 be managed? How can we prevent the dissemination of fake news? The World Health Organization (WHO) decided to refer to it as "infodemic" when various types of information about studies are quoted but whose authors' seriousness and suitability have not been adequately verified and whose scientific and methodological development have not been subjected to peer-review.

Readers should be warned about the availability of articles whose quality, validity, and methodological rigor have not been assessed in pursuit of a rapid dissemination to the scientific community.

During this short period of time, several publications have contradicted other subsequent reports because they have shown methodological errors in research protocols or were done with certain drugs that proved to be ineffective.

This calls for an ongoing discrimination of the information provided to society from day to day.

From scientific medical journals, we need to balance editorial controls regarding the scientific quality, veracity, and accuracy of manuscripts and the speed of publication times given the urgent need for a response to the pandemic's advance.

For some time now, it has been proposed that articles sent to journals should be available to the medical and non-medical community before their review or after a general review by journal editors (before or simultaneously with peer review). These are known as preprints and are increasingly considered a quick source of communication. However, it is worth noting that a study's information or findings may be questioned, changed, corrected or taken back if concerns about the investigation or errors in results emerge.

On the one side, as of May $5^{\text {th }}$, PubMed alone included 8599 articles under the term coronavirus; 1171 under coronavirus children; 8646 under SARS-CoV-2 infection; 1909 under COVID SARS; 473 under COVID-19 children; 135 under COVID-19 pregnancy; 190 under COVID-19 treatment, and several other articles under other health-related terms already published in indexed journals.

On the other side, several and varied research trials about COVID-19 and related topics are being developed in different countries; ClinicalTrials featured, as of May $5^{\text {th }}$, a total of 1208 registered studies. Likewise, as of the same date, the WHO database included 980 studies, in addition to other research protocols registered before the public agencies of each country.

Therefore, it is expected that medical (and non-medical) information related to the pandemic will keep growing exponentially, certainly for the next months and probably for the next years, as research studies are developed, completed, and results become published.

Medical journal editors should warrant that quality standards for publication are met in accordance with the recommendations of the International Committee of Medical Journal Editors (ICMJE). Therefore, a strict peer review is an essential cornerstone, which is hard to accomplish now that health care providers are mainly devoted to patient care. In addition, authors are recommended to identify, before submitting their articles, the characteristics of the peer-reviewed scientific journal and to assess its integrity, reputation, practices, and history. 
The urgency to disseminate information about the COVID-19 pandemic should not be a barrier to meeting good research practice or warranting adherence to quality and ethical standards for publications.

During this time when urgency sanctions the immediate publication of any experience, without an in-depth analysis of quality, the community as a whole should be aware of its limitations, cautious about its acceptance, and critical of information.

\section{Adriana Aguilar Assistant Editor}

http: / / dx.doi.org/10.5546/ aap.2020.eng.226

To cite: Aguilar A. COVID-19. Considerations about the overwhelming and indiscriminate scientific information and its dissemination. Arch Argent Pediatr 2020;118(4):226-227.

\section{REFERENCES}

- Recomendaciones y noticias. Ministerio de salud Argentina. [Accessed on: 5-5-2020]. Available at: https://www. argentina.gob.ar/salud/coronavirus-COVID-19
- Covid-19-recomendaciones- atención- embarazadas-recién nacidos. [Accessed on:5-5-2020]. Available at: http: / / www. msal.gob.ar/images/stories/bes/graficos/ 0000001839 cntcovid-19-recomendaciones-atencion-embarazadas-reciennacidos.pdf

- Sociedad Argentina de Pediatría. Available at: https: / / www. sap.org.ar/

- Preprints. [Accessed on: 5-5-2020]. Available at: https:// preprints.scielo.org/index.php/scielo

- ClinicalTrials. [Accessed on:5-5-2020]. Available at:https:// clinicaltrials.gov / ct2/ results?cond=COVID-19

- Cdc.gov. [Accessed on:5-5-2020]. Availableat:https:/ / www. cdc.gov/ coronavirus/2019-ncov/hcp/therapeutic-options. html

- OMS. [Accessed on: 5-5-2020]. Available at: https:// clinicaltrials.gov/ct2/who_table

- La desinformación frente a la medicina: hagamos frente a la infodemia. [Accessed on: 5-5-2020]. Available at: https: / / www.who.int/es/news-room/ commentaries/detail/ coronavirus-infodemic

- International Committee of Medical Journal Editors. Recommendations for the Conduct, Reporting, Editing, and Publication of Scholarly work in Medical Journals. ICMJE; 2019. [Accessed on: 5-5-2020]. Available at: http:/ / www.icmje.org/recommendations / browse/roles-andresponsibilities / responsibilities-in-the-submission-andpeer-peview-process.html 